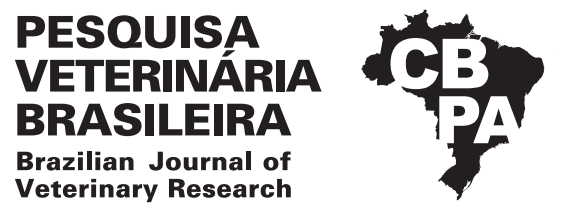

Pesq. Vet. Bras. 38(8):1577-1583, agosto 2018 DOI: 10.1590/1678-5150-PVB-5645

Original Article

Animais de Produção/Livestock Diseases

ISSN 0100-736X (Print)

ISSN 1678-5150 (Online)

\title{
Proteolytic and lipolytic potential of Pseudomonas spp. from goat and bovine raw milk ${ }^{1}$
}

\author{
José C. Ribeiro Júnior ${ }^{2 *}$, Pedro I. Teider Junior², André L.M. Oliveira ${ }^{3}$, \\ Edson A. Rios ${ }^{2}$, Ronaldo Tamanini ${ }^{2}$ and Vanerli Beloti ${ }^{2}$
}

\begin{abstract}
Ribeiro Júnior J.C., Teider Junior P.I., Oliveira A.L.M., Rios E.A., Tamanini R. \& Beloti V. 2018. Proteolytic and lipolytic potential of Pseudomonas spp. from goat and bovine raw milk. PesquisaVeterinária Brasileira 38(8):1577-1583. Instituto Nacional de Ciência e Tecnologia para a Cadeia Produtiva do Leite, Departamento de Medicina Veterinária Preventiva, Universidade Estadual de Londrina, Cx. Postal 11.011, Londrina, PR 86 057-970, Brazil. E-mail: ribeirojuniorjc@gmail.com

Pseudomonas, the main genus of gram-negative microorganisms isolated from milk, is psychrotrophic, biofilm-forming, and thermo-resistant deteriorating enzyme producers. The aim of this study was to quantify Pseudomonas spp. in goat's and cow's milk produced in the Paraná state, Brazil, to evaluate the deteriorating activity of the isolates at mesophilic and psychrotrophic conditions and to identify, at the species level, the isolates with alkaline metalloprotease (aprX gene) production potential. Microbiological, biochemical and molecular methods were used for isolating, confirming and identifying of isolates. The mean counts were $1.6( \pm 6.3) \times 10^{4}$ and $0.89( \pm 3) \times 10^{2} \mathrm{CFU} / \mathrm{mL}$ for goat and bovine milk samples, respectively, immediately after milking. Of the Pseudomonas colonies isolated from goat milk $(\mathrm{n}=60), 91.7 \%$ showed proteolytic potential when incubated at $35^{\circ} \mathrm{C} / 48 \mathrm{~h}$ and $80 \%$ at $7^{\circ} \mathrm{C} / 10$ days, and lipolytic potential was observed in $95 \%$ of the isolates incubated in mesophilic and $78.3 \%$ at refrigeration conditions. From the isolates of bovine milk $(n=20)$, $35 \%$ showed proteolytic activity only when incubated at $35^{\circ} \mathrm{C} / 48 \mathrm{~h}$, and lipolytic potential was observed in $25 \%$ of the isolates incubated at $7{ }^{\circ} \mathrm{C} / 10 \mathrm{~d}$ and $35^{\circ} \mathrm{C} / 48 \mathrm{~h}$. It was observed that $83.3 \%$ and $25 \%$ of the isolates genetically confirmed as Pseudomonas spp. of goat and bovine milk showed the potential for alkaline metalloprotease production, with the species $P$. azotoformans, $P$. koreensis, $P$. gessardii, $P$. monteilii and $P$. lurida being the most frequent in goat milk and $P$. aeruginosa the only species identified in cow milk.
\end{abstract}

INDEX TERMS: Proteolytic, lipolytic, Pseudomonas spp., goat, bovine, milk, alkaline metalloprotease, microbial diversity, psychrotrophic, spoilage, bacterioses.

RESUMO.- [Potencial proteolítico e lipolítico de espécies de Pseudomonas do leite cru caprino e bovino.] Pseudomonas é o principal gênero de micro-organismos Gram negativos isolados do leite, são psicrotróficos, formadores de biofilmes e produtores de enzimas deteriorantes termodúricas. 0 objetivo do presente trabalho foi quantificar Pseudomonas spp. no

\footnotetext{
${ }^{1}$ Received on December 14, 2017.

Accepted for publication on December 22, 2017.

${ }^{2}$ Instituto Nacional de Ciência e Tecnologia para a Cadeia Produtiva do Leite, Departamento de Medicina Veterinária Preventiva, Universidade Estadual de Londrina, Cx. postal 10.011, Londrina, PR 86 057-970, Brazil. *Corresponding author: ribeirojuniorjc@gmail.com

${ }^{3}$ Departamento de Bioquímica e Biotecnologia, Universidade Estadual de Londrina, Cx. postal 10.011, Londrina, PR 86 057-970.
}

leite de cabras e vacas produzido no estado do Paraná, Brasil, avaliar a atividade deteriorante em temperatura mesofílica e psicrotrófica e identificar, em nível de espécie, os isolados com potencial de produção de metaloprotease alcalina (gene $a p r X$ ). Foram utilizados métodos microbiológicos, bioquímicos e moleculares para isolamento, confirmação e identificação dos isolados. As contagens médias foram de $1,6( \pm 6,3) \times 10^{4}$ e $0,9( \pm 3) \times 10^{2} \mathrm{UFC} / \mathrm{mL}$ para as amostras de leite caprino e bovino, respectivamente. Dos isolados de Pseudomonas do leite de cabra ( $\mathrm{n}=60), 91,7 \%$ demonstraram potencial proteolítico quando incubadas a $35^{\circ} \mathrm{C} / 48 \mathrm{~h}$ e $80 \%$ a $7^{\circ} \mathrm{C} / 10$ dias e lipolíticos em $95 \%$ dos isolados incubados em mesofilia e em 78,3\% dos incubados em temperatura de refrigeração. Dos isolados do leite bovino $(n=20)$, foi verificada 
atividade proteolítica de 35\% apenas quando incubadas a $35^{\circ} \mathrm{C} / 48 \mathrm{~h}$ e lipolítica em $25 \%$ dos isolados incubados a $7^{\circ} \mathrm{C} / 10 \mathrm{~d}$ e $35^{\circ} \mathrm{C} / 48 \mathrm{~h}$. Foi observado que $83,3 \%$ e $25 \%$ dos isolados confirmados geneticamente como Pseudomonas spp. do leite caprino e bovino, respectivamente, apresentaram o potencial de produção de metaloprotease alcalina, sendo as espécies $P$. azotoformans, $P$. koreensis, $P$. gessardii, $P$. monteilii e $P$. lurida as mais frequentes no leite de cabras e $P$. aeruginosa a única identificada do leite de vacas.

TERMOS DE INDEXAÇÃO: Proteolítico, lipolítico, Pseudomonas spp., leite, caprinos, bovinos, deteriorantes, diversidade microbiana, metaloprotease alcalina, psicrotróficos, bacterioses.

\section{INTRODUCTION}

Microorganisms of the Pseudomonas genus are especially important for the quality of fluid milk and dairy products since they are considered dominant among the psychrotrophs (Dogan \& Boor 2003, Xin et al. 2017) and are important biofilm makers (Teh et al. 2014), which is based on the production of proteolytic and lipolytic enzymes (Law 1991, Sørhaug \& Stepaniak 1997, Baur et al. 2015). Among Gram-negative bacteria isolated from milk, Pseudomonas is the genus with the highest potential for protease production (Sørhaug \& Stepaniak 1997, Baur et al. 2015). These enzymes can resist pasteurization and treatment by ultra-high temperature (UHT) processes (Alves et al. 2016), reducing the shelf-life of fluid milk and causing sensorial changes in dairy products (Law 1991).

Pseudomonas can produce proteases in a wide temperature range (Teh et al. 2014) and multiply at temperatures up to $45^{\circ} \mathrm{C}$ (Caldera et al. 2016), $47 \%$ of the isolates in milk show proteolytic activity in quantitative assays (Caldera et al. 2016). These proteases can maintain $40 \%$ of their activity after treatment at $100^{\circ} \mathrm{C}$ for 5 minutes (Alves et al. 2016) and $50 \%$ when stored at $4^{\circ} \mathrm{C}$ for up to 12 days (Oh et al. 2000).

The metalloproteases are the main proteases produced by Pseudomonas (Ertan et al. 2015) and are important in the process of deterioration of food, especially in milk, because the availability of calcium makes it difficult to denature the proteases, conferring greater thermal resistance (Ertan et al. 2015, Stoeckel et al. 2016). In UHT milk, casein hydrolysis by metalloproteases causes gelling (Matéos et al. 2015, Stuknytè et al. 2016), and fermented or matured dairy products have a bitter taste (Fairbairn \& Law 1986) mainly because these enzymes maintain proteolytic activity at $\mathrm{pH}$ levels between 5 and 10 (Matéos et al. 2015). In addition, they account for $60 \%$ of the world trade of enzymes (Kuddus \& Ramteke 2012), emphasizing the importance of knowledge of the genera and species of microorganisms that produce these proteases due to their biotechnological potential.

The lipolytic activity of the microorganisms of the genus Pseudomonas, especially of the species P. fluorescens, is also important for industrial and chemical processes (Hakiminia et al. 2013). However, these lipases also act negatively on the quality of milk and derivatives, and little is known about the lipolytic activity of other Pseudomonas spp.

Due to the importance of the genus in goat and bovine milk, the aim of this study was to quantify Pseudomonas spp. isolates from the milk of goats and cows by confirmation with genus-specific $16 \mathrm{~S}$ rRNA PCR, to evaluate the proteolytic and lipolytic potential in mesophilic and psychrotrophic temperatures, and to identify, at the species level, the strains with the potential to produce alkaline metalloprotease $(\operatorname{apr} X)$.

\section{MATERIALS AND METHODS}

Milk samples. Thirty-six samples of goat's milk and 20 samples of bovine milk from the state of Paraná, Brazil, were evaluated between November 2014 and May 2015. Samples were collected immediately after milking directly from bulk tanks in sterile flasks and sent under refrigeration to the Inspection of Animal Origin Products Laboratory of the State University of Londrina, Paraná, Brazil. Each milk sample was collected from different dairy farms and only one sample (500mL) was collected from each bulk tank.

Pseudomonas count and biochemical tests. The counts of Pseudomonas spp. were carried out in accordance with ISO 11.059 (ISO 2009). After dilution of the milk in buffered peptone water until $10^{-5}$, the samples were seeded $(0.1 \mathrm{~mL})$ in duplicate in pseudomonas agar base (Oxoid, Basingstoke, England), supplemented with potassium penicillin G (100,000 IU/L) (Sigma-Aldrich Biotechnology, St Louis, USA) and Pimaricin (0.01g/L) (Sigma), and incubated at $25^{\circ} \mathrm{C}$ for 48hours.

For biochemical confirmation, all the obtained colonies were subjected to glucose fermentation and oxidase production tests, according with ISO 11.059 (2009). Only the colonies that presented a negative result in the fermentation of the glucose and a positive result for the oxidase production were considered for counting, being the results considered after the correction of the seeded volume to one $\mathrm{mL}\left(10^{1}\right)$ and the dilution used for counting in each sample.

DNA extraction. All isolates that showed biochemical results compatible with Pseudomonas spp. were cultured in tryptic soy broth (TSB) (Acumedia, Baltimore, USA) at $30^{\circ} \mathrm{C}$ for 48 hours to extract DNA by simple boiling as described by Ribeiro Júnior et al. (2016). The extracts were quantified (Qubit ${ }^{\circledR}$ dsDNA HS Assay Kit, Invitrogen, Carlsbad, USA) and stored at $-20^{\circ} \mathrm{C}$ for PCR assays.

Deteriorating potential. To verify the proteolytic capacity of the strains at mesophilic and refrigeration temperatures, after sowing in milk agar (Acumedia, Baltimore, USA) supplemented with $10 \%$ reconstituted skimmed milk powder (Hantsis-Zacharov \& Halpern 2007), plaques were incubated at $35^{\circ} \mathrm{C}$ for 48 hours and at $7^{\circ} \mathrm{C}$ for 10 days. The proteolytic activity of the isolates was verified by the formation of translucent halos around the colonies.

The alkaline metalloprotease production potential was confirmed using PCR of the aprX gene according to Bach et al. (2001). PCR primers and conditions are described in Table 1.

The PCR was performed with approximately 50ng DNA template, $100 \mathrm{nM}$ of each deoxynucleotide, $5 \mu \mathrm{l} 10 \mathrm{X}$ buffer, $75 \mathrm{mmol} \mathrm{L}^{-1} \mathrm{MgCl}_{2}$, $20 \mathrm{pmol} \mathrm{L}^{-1}$ of each primer, and $2.5 \mathrm{U}$ of Platinum Taq DNA polymerase (Invitrogen, Carlsbad, USA). Amplification was performed in a thermocycler (AerisTM Thermal Cycler, Esco Micro Pte. Ltd., Singapore) and the PCR amplified DNA samples were applied to a $1 \%$ agarose gel (Invitrogen) and subjected to electrophoresis for 1 hour at a constant voltage of $90 \mathrm{~V}$. The gels were stained with ethidium bromide solution at $0.2 \mathrm{mg} \cdot \mathrm{ml}^{-1}$ for 20 minutes and visualized in UV transilluminator.

The lipolytic potential of the isolates was evaluated by plating the colonies on tributyrin agar (HiMedia, Mumbai, India) supplemented with 1\% tributyrin (HiMedia) (Hantsis-Zacharov \& Halpern 2007). The formation of translucent halos around the colonies after 48 hours of incubation at $30^{\circ} \mathrm{C}$ or 10 days at $7^{\circ} \mathrm{C}$ was considered positive for lipase production potential. 
Table 1. Primers and PCR cycling conditions

\begin{tabular}{|c|c|c|c|c|}
\hline Gene & Primers (5'-3') & Size (pb) & PCR cycling conditions & Reference \\
\hline$a p r X$ & $\begin{array}{l}\text { TAYGGBTTCAAYTCCAAYAC } \\
\text { VGCGATSGAMACRTTRCC }\end{array}$ & 194 & $\begin{array}{c}94^{\circ} \mathrm{C}-5 \mathrm{~m} \\
30 \mathrm{x}\left(94^{\circ} \mathrm{C}-30 \mathrm{~s}, 53^{\circ} \mathrm{C}-30 \mathrm{~s},\right. \\
\left.72^{\circ} \mathrm{C}-20 \mathrm{~s}\right) \\
72^{\circ} \mathrm{C}-10 \mathrm{~m}\end{array}$ & Bach et al. (2001) \\
\hline $\begin{array}{l}\text { 16S rRNA Pseudomonas } \\
\text { genus-specific }\end{array}$ & $\begin{array}{l}\text { GAGTTTGATCMTGGCTCAG } \\
\text { GGYTACCTTGTTACGACTT }\end{array}$ & 618 & $\begin{array}{c}95^{\circ} \mathrm{C}-2 \mathrm{~m} \\
25 \mathrm{x}\left(94^{\circ} \mathrm{C}-20 \mathrm{~s}, 54^{\circ} \mathrm{C}-20 \mathrm{~s},\right. \\
\left.72^{\circ} \mathrm{C}-40 \mathrm{~s}\right) \\
72^{\circ} \mathrm{C}-1 \mathrm{~m}\end{array}$ & Spilker et al. (2004) \\
\hline
\end{tabular}

Confirmation and determination of Pseudomonas spp. For confirmation of the genus, all isolates characterized as Pseudomonas spp. by the biochemical method were submitted to PCR for amplification of a specific region of the 16S rRNA gene, with the primers and reaction conditions described in Table 1.

For the identification of the isolates that showed alkaline metalloprotease production potential $(\operatorname{apr} X)$, partial amplification of the 16S rRNA gene was performed using the primers and reaction conditions described in Table 1. The products of this PCR were purified (PureLink ${ }^{\mathrm{TM}}$ Genomic DNA Purification Kit, Invitrogen) and quantified (Invitrogen) for DNA sequencing by the Sanger method (ABI 3500 Genetic Analyzer, Applied Biosystems, Foster City, USA) in both directions.

The quality of the sequences was evaluated by BioEdit v.7.2.5, and the consensus sequences were generated by CAP 3 (Huang \& Madan 1999). Using Clustal W, these sequences were individually aligned with sequences representative of the 164 species of the genus Pseudomonas available from the Ribosomal Database Project (RDP). Phylogenetic analysis was performed using the Neighbor-joining method and the Tamura-Nei model using bootstrap support for 1000 replicates in MEGA v.7.0 (Kumar et al. 2016).

\section{RESULTS AND DISCUSSION}

The plaque counts of Pseudomonas spp. ranged from $1 \mathrm{UFC} / \mathrm{mL}$ to $3.7 \times 10^{5} \mathrm{CFU} / \mathrm{mL}$ for goat milk, with an average of $1.6( \pm 6.3)$ $\mathrm{x} 10^{4} \mathrm{CFU} / \mathrm{mL}$. For bovine milk, the counts were considerably lower, varying from $<10$ until $1.3 \times 10^{3} \mathrm{CFU} / \mathrm{mL}$, with a mean of $0.89( \pm 3) \times 10^{2} \mathrm{CFU} / \mathrm{mL}$. These results can be attributed to technological differences and hygienic practices between properties. The cattle-producing properties studied are highly technified, use treated water, have good environmental hygiene and rigorous milking hygiene practices, and 95.2\% of samples had total bacterial counts lower than $10^{5} \mathrm{CFU} / \mathrm{mL}$ (Ribeiro Júnior et al. 2015), which was not observed with goat milk properties. Milkers' hands, surface of cows' teats, teat cups and cooling tanks were associated with raw milk contamination with Pseudomonas spp. on farms with manual and mechanical milking system, showing that regardless of the type of milking system and season, proper hygiene procedures of equipment, utensils and workers' hands are essential to avoid contamination of raw milk (Vidal et al. 2017).

In Minas Gerais state, Brazil, Scatamburlo et al. (2015) verified a mean of $8 \times 10^{3} \mathrm{CFU} / \mathrm{mL}$ of Pseudomonas spp. in goat milk samples collected from refrigeration tanks. The counts of
Pseudomonas spp. can increase rapidly in bulk tanks, increasing from 2 to $4.5 \log \mathrm{CFU} / \mathrm{mL}$ at $6^{\circ} \mathrm{C}$ (De Jonghe et al. 2011) or $1.4 \times 10^{4}$ to $1.8 \times 10^{6} \mathrm{CFU} / \mathrm{mL}$ at $4^{\circ} \mathrm{C}$ (Capodifoglio et al. 2016) during 96 hours of storage in bulk tanks.

Considering biochemical tests of glucose fermentation and oxidase, 63 isolates of Pseudomonas were obtained from goat milk and 36 from bovine milk. By PCRs specific for a region of the 16S rRNA gene, 60 (95.2\%) of goat milk and 20 (55.5\%) bovine milk isolates were confirmed as Pseudomonas, shown in Table 2.

Among the isolates from goat milk identified by the $16 \mathrm{~S}$ rRNA PCR as belonging to the genus Pseudomonas, 91.7\% demonstrated proteolytic potential when incubated at $35^{\circ} \mathrm{C} / 48 \mathrm{~h}$ and $80 \%$ at $7{ }^{\circ} \mathrm{C} / 10 \mathrm{~d}$; lipolysis was observed in $95 \%$ of the isolates incubated at mesophilic temperature and in $78.3 \%$ incubated at refrigeration temperature (Table 2).

It is known that the proteolytic and/or lipolytic activity is favored in refrigeration temperature, in relation to saccharolytic activity (lactose degradation), due to the lower activity energy required for proteases and lipases in relation to lactase, which has an optimal temperature of $35^{\circ} \mathrm{C}$ (Oliveira et al. 2015).

Many studies conclude that the multiplication under refrigeration conditions is favored by the proteolytic and/or lipolytic capacity of the Pseudomonas (Oh et al. 2000, HantsisZacharov \& Halpern 2007, Capodifoglio et al. 2016, Xin et al. 2017). In this study the most of the isolates from goat milk presented proteolytic and lipolytic capacities simultaneously and better expressed this capacity at a mesophilic temperature. The potential deterioration represented by Pseudomonas in goat milk samples evaluated by the present work will interfere with the shelf life of processed fluid milk and the sensorial quality of dairy products.

For the isolates confirmed as Pseudomonas spp. in bovine milk, $35 \%$ were proteolytic at $35^{\circ} \mathrm{C} / 48 \mathrm{~h}$. However, no proteolytic activity was observed when the isolates were incubated at $7^{\circ} \mathrm{C} / 10 \mathrm{~d}$. For lipolysis, $25 \%$ of bovine milk isolates demonstrated this capacity at $35^{\circ} \mathrm{C} / 48 \mathrm{~h}$ and $7^{\circ} \mathrm{C} / 10 \mathrm{~d}$. Thus, in bovine milk, in addition to low counts, most of the isolates did not show potential for deterioration, especially at the refrigeration temperature, milk storage condition observed rigorously in all the properties studied. Baur et al. (2015) evaluated the deteriorating activity of Pseudomonas in bovine milk and verified that only $9.3 \%$ of the isolates of Pseudomonas had lipolytic activity. 
As for the alkaline metalloprotease production potential (aprXgene) of the isolates confirmed as Pseudomonas, 49 strains in goats' milk (81.6\%) and 5 (25\%) from bovine milk presented the gene. For bovine milk, all isolates positive for the aprXgene were obtained from a single milk sample. That is, 19 (95\%) of the 20 bovine milk samples did not present any Pseudomonas potentially producing metalloprotease. In a similar study, Caldera et al. (2016) observed the presence of the aprX gene in $71.2 \%$ of the Pseudomonas isolates of bovine milk, reaffirming a higher quality and greater technological potential of bovine raw milk samples evaluated by the present study.
Additionally, five of the goats' milk isolates confirmed by PCR as Pseudomonas spp. that did not show the potential for alkaline metalloprotease production (aprXgene) phenotypically showed proteolytic activity in milk agar, which may be related to the production of other proteases.

The identification of the species of Pseudomonas with alkaline metalloprotease producing potential allowed us to verify the great diversity of the isolates of the goat's milk, from which 21 different species were identified (Table 3). The dominant species were $P$. azotoformans, $P$. koreensis, P. gessardii, P. monteilii and P. lurida. On the other hand,

Table 2. Pseudomonas strains isolated from goat and bovine milk, biochemical identification, molecular confirmation, alkaline metalloprotease production potential $(a p r X)$ and proteolytic and lipolytic activity in plaques

\begin{tabular}{|c|c|c|c|c|c|c|c|c|c|c|c|c|c|}
\hline \multirow{3}{*}{$\begin{array}{l}\text { Milk } \\
\text { origin }\end{array}$} & \multirow{3}{*}{$\begin{array}{c}\text { Pseudomonas } \\
\text { spp. biochemical } \\
\text { confirmation }^{\mathrm{a}}(\mathrm{n})\end{array}$} & \multirow{2}{*}{\multicolumn{2}{|c|}{$\begin{array}{c}\text { Pseudomonas spp. } \\
\text { PCR confirmation } \\
\text { approach }\end{array}$}} & \multicolumn{4}{|c|}{ Proteolysis } & \multicolumn{4}{|c|}{ Lipolysis } & \multirow{2}{*}{\multicolumn{2}{|c|}{$\begin{array}{l}\text { Presence of } \\
\operatorname{aprXgene}^{b}\end{array}$}} \\
\hline & & & & \multicolumn{2}{|c|}{$35^{\circ} \mathrm{C} / 48 \mathrm{~h}$} & \multicolumn{2}{|c|}{$7^{\circ} \mathrm{C} / 10 \mathrm{~d}$} & \multicolumn{2}{|c|}{$35^{\circ} \mathrm{C} / 48 \mathrm{~h}$} & \multicolumn{2}{|c|}{$7^{\circ} \mathrm{C} / 10 \mathrm{~d}$} & & \\
\hline & & $\mathrm{n}$ & $\%$ & $\mathrm{n}$ & $\%$ & $\mathrm{n}$ & $\%$ & $\mathrm{n}$ & $\%$ & $\mathrm{n}$ & $\%$ & $\mathrm{n}$ & $\%$ \\
\hline Goat & 63 & 60 & 95.2 & 55 & 91.7 & 48 & 80 & 57 & 95 & 47 & 78.3 & 49 & 81.6 \\
\hline Cow & 36 & 20 & 55.5 & 7 & 35 & 0 & & 5 & 25 & 5 & 25 & 5 & 25 \\
\hline
\end{tabular}

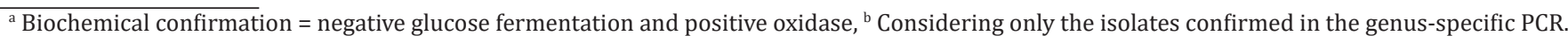

Table 3. Pseudomonas spp. positive for the aprX gene isolated from Brazilian goat and bovine raw milk, and expression of proteolytic and lipolytic activity at mesophilic and psychrotropic temperatures

\begin{tabular}{|c|c|c|c|c|c|c|c|}
\hline \multirow{2}{*}{ Pseudomonas species } & \multicolumn{2}{|c|}{ Total } & \multirow{2}{*}{ Milk sample } & \multicolumn{2}{|c|}{ Proteolytic } & \multicolumn{2}{|c|}{ Lipolytic } \\
\hline & $\mathrm{n}$ & $\%$ & & $35^{\circ} \mathrm{C} / 48 \mathrm{~h}$ & $7^{\circ} \mathrm{C} / 10 \mathrm{~d}$ & $35^{\circ} \mathrm{C} / 48 \mathrm{~h}$ & $7^{\circ} \mathrm{C} / 10 \mathrm{~d}$ \\
\hline P. azotoformans & 8 & 14.8 & Goat & 8 & 8 & 8 & 8 \\
\hline P. aeruginosa & 5 & 9.2 & Cow & 3 & 0 & 3 & 3 \\
\hline P. gessardii & 3 & 5.6 & Goat & 3 & 3 & 3 & 3 \\
\hline P. lurida & 3 & 5.6 & Goat & 2 & 2 & 3 & 3 \\
\hline P. lini & 2 & 3.7 & Goat & 2 & 2 & 2 & 2 \\
\hline P. kilonensis & 2 & 3.7 & Goat & 2 & 2 & 2 & 2 \\
\hline P. mucidolens & 2 & 3.7 & Goat & 2 & 2 & 2 & 2 \\
\hline P. proteolytica & 2 & 3.7 & Goat & 2 & 2 & 2 & 2 \\
\hline P. veronii & 2 & 3.7 & Goat & 2 & 2 & 2 & 2 \\
\hline P. fluorescens & 1 & 1.6 & Goat & & 1 & 1 & \\
\hline P. jessenii & 1 & 1.6 & Goat & 1 & 1 & 1 & 1 \\
\hline P. lundensis & 1 & 1.6 & Goat & 1 & 1 & 1 & \\
\hline P. mediterranea & 1 & 1.6 & Goat & 1 & 1 & 1 & 1 \\
\hline P. migulae & 1 & 1.6 & Goat & 1 & 1 & 1 & 1 \\
\hline P. panacis & 1 & 1.6 & Goat & 1 & 1 & 1 & 1 \\
\hline P. plecoglossicida & 1 & 1.6 & Goat & 1 & 1 & 1 & \\
\hline P. salomonii & 1 & 1.6 & Goat & 1 & 1 & 1 & 1 \\
\hline P. simiae & 1 & 1.6 & Goat & & & 1 & \\
\hline P. taetrolens & 1 & 1.6 & Goat & & 1 & & 1 \\
\hline
\end{tabular}


$P$ aeruginosa was the only species identified in bovine milk. This genetic diversity is also represented in Figure 1.

The diversity of strains observed in goat milk (Fig.1) is likely related to the lack of hygienic practices in milking, which allows a wide range of microorganisms to come into contact with milk. From the perspective of the microbial ecology of goats' milk, this diversity means low selective pressure in the environment, conferring a high diversity of Pseudomonas species. However, the samples of bovine milk, from better hygiene conditions, in addition to low counts, showed no variability. P. aeruginosa is an opportunistic microorganism in the environment, especially in water, that can cause mastitis and metritis and remain in the herd (Wright et al. 2015, Nan et al. 2016).

During the manual milking of cows, same process of obtaining goat milk samples as in the present study, Capodifoglio et al. (2016) found that the Pseudomonas counts on the surface of ceilings after pre-dipping reached $1.08 \times 10^{4} \mathrm{CFU} / \mathrm{mL}$ and on the cooling tank surfaces at $4.1 \times 10^{4} \mathrm{CFU} / \mathrm{mL}$. This high contamination by Pseudomonas in the manual milking environment, often lacking hygienic measures, treated water, and the use of sanitizing substances, can influence the diversity of species of the genus in the milk of goats.

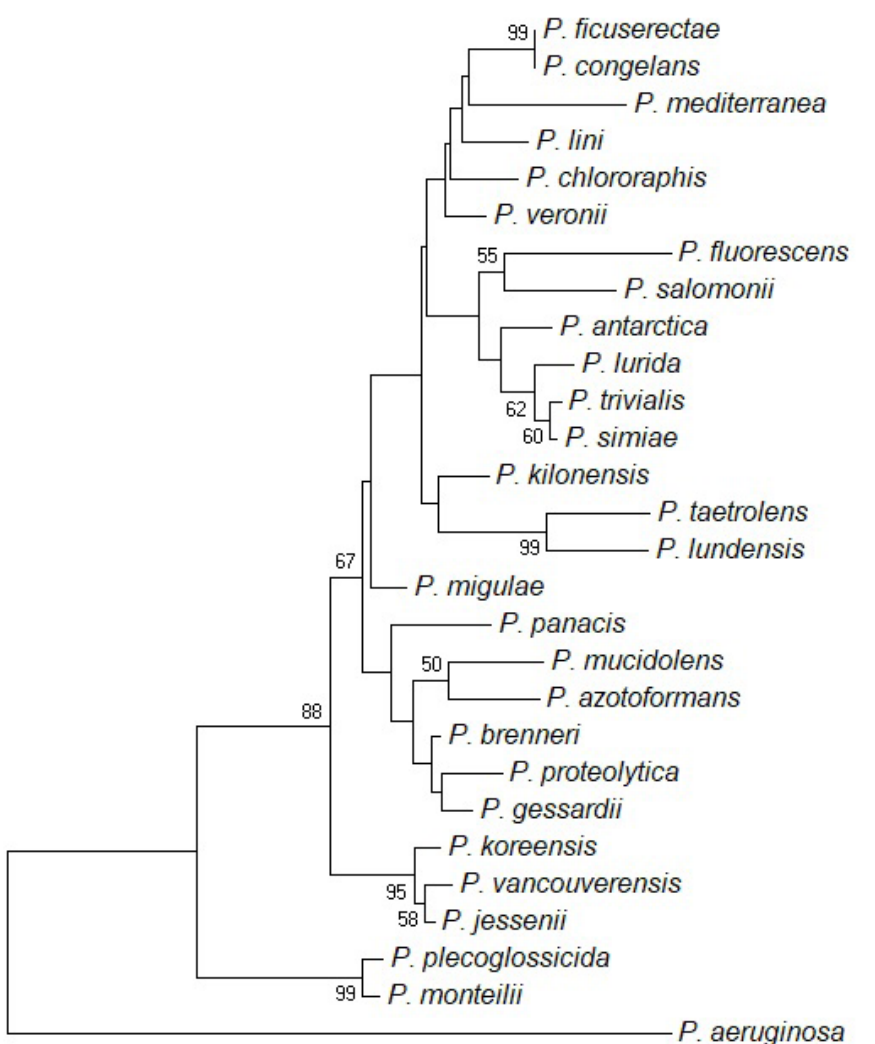

0.005

Fig.1. Neighbour-joining phylogenetic tree based on 16S rRNA gene sequences of Pseudomonas species potentially producing alkaline metalloprotease isolated from cows and goats raw milk samples. Numbers at nodes are percentages of bootstrap values $(>50 \%$ ) obtained by repeating analysis 1000 times to generate majority consensus tree. Scale bar indicates 0.005 nucleotide sequence divergence.
As for the proteolytic activity of Pseudomonas species positive for the aprX gene isolated from goat milk, some weights can be determined from Table 3. For example, from 3 strains of $P$. lurida, 1 showed no proteolytic activity at $35^{\circ} \mathrm{C} / 48 \mathrm{~h}$, and another strain was not proteolytic at $7^{\circ} \mathrm{C} / 10 \mathrm{~d}$. The strain identified as $P$. taetrolens did not show proteolysis or lipolysis at $37^{\circ} \mathrm{C} / 48 \mathrm{~h}$ but was proteolytic and lipolytic at $7^{\circ} \mathrm{C} / 10 \mathrm{~d}$. The strain of $P$. fluorescens was only proteolytic at $7^{\circ} \mathrm{C} / 10 \mathrm{~d}$ and only lipolytic at $35^{\circ} \mathrm{C} / 48 \mathrm{~h}$. P. simiae presented only lipolytic activity at $35^{\circ} \mathrm{C} / 48 \mathrm{~h}$. P. plecoglossicida did not show lipolysis at $7^{\circ} \mathrm{C} / 10 \mathrm{~d}$. Finally, the isolate identified as $P$. congelans did not present deteriorating activity, although it was positive for the aprX gene.

These observations, as reported in the study by Scatamburlo et al. (2015), indicate that variations in gene expression should be influenced by other genes or factors since the isolates of the same species with the $a p r X$ gene were observed either expressing the gene at different temperatures or not expressing it. Furthermore, there are proteolytic samples that do not carry the $\operatorname{aprX}$ gene, indicating that other proteases are being produced and that the proteolysis observed in the samples bearing the aprX gene may not be due to expression of this gene.

P. fluorescens represented only $1.8 \%$ of the Pseudomonas strains isolated from goat milk in this study and expressed proteolysis only at refrigeration temperature. However, their deteriorating milk activity should not be underestimated since recent studies point to the pronounced multiplication of this species in milk maintained at $4^{\circ} \mathrm{C}$, increasing from 3 to $8.5 \log \mathrm{CFU} / \mathrm{mL}$ in 170 hours (Lin et al. 2016). Scatamburlo et al. (2015) also verified the dominance of P. fluorescens in goat's milk (50\% of the isolates), considering the identification through a species-specific PCR.

The 5 isolates of bovine milk bearing the aprX gene were identified as P. aeruginosa. Although these isolates originated from the same bovine milk sample, only 3 presented proteolytic activity at $35^{\circ} \mathrm{C} / 48 \mathrm{~h}$, and none presented proteolysis at $7^{\circ} \mathrm{C} / 10 \mathrm{~d}$, emphasizing the influence of other factors on gene expression and proteolysis as well as the low deteriorating activity of Pseudomonas in the bovine milk samples evaluated by the present study, especially when maintained under refrigeration.

It is important to note that the gene encoding alkaline metalloprotease synthesis is extensively distributed among the Pseudomonas species, and almost all goat milk isolates showed a production capacity of proteases and lipases that can maintain activity even after thermal treatments of milk that eliminate the vegetative forms of Pseudomonas.

The concern with the deteriorating enzymes produced by Pseudomonas is so great that some alternatives have been proposed to reduce the technological problems caused by them in UHT milk and derivatives, such as the use of purified Pseudomonas phages for the control of the microorganisms of the genus itself and other psychrotropic agents (Hu et al. 2016), using colorimetric methods applied to goat and sheep milk for the quantification of proteolytic activity for milk sorting of lots (Palomba et al. 2017), and other methods to deactivate these enzymes in milk destined for the production of long shelf-life dairy products (Stoeckel et al. 2016).

However, avoiding the contamination of raw milk by Pseudomonas is shown as the best way to control the problems 
arising from the microbial enzymatic deterioration of milk and milk products. The correct treatment of water and the hygiene of systems for obtaining, storing and transporting milk are sufficient to control contamination of raw milk by Pseudomonas of any species, as well as other spoilage micro-organisms.

\section{CONCLUSIONS}

Considering that the milk samples were collected shortly after milking, high Pseudomonas spp. counts were observed in goat's milk and a great variety of species carrying the gene $a p r X$, mainly attributed to the absence of environmental selective pressure due to the lack of hygiene maintenance of goat milk production systems. For bovine milk, the reduction of initial bacterial counts in raw milk to very low levels was a limiting factor for counts and diversity of Pseudomonas with spoilage potential.

The $\operatorname{apr} X$ gene is dispersed among numerous species of Pseudomonas and, with it, the proteolytic potential. It is evident, that the gene expression depends on factors not elucidated and not linked to the species, and it is clear that other proteases are produced by the genus Pseudomonas. It is certain, however, that the activity of heat-stable proteases, including alkaline metalloprotease, and of lipolytic enzymes originating from Pseudomonas spp. is the limiting factor in maintaining the quality of milk.

Acknowledgments.- The authors are grateful for the collaboration of the researchers Amauri Alcindo Alfieri (recipient of CNPq fellowships), Elis Lorenzetti and Edsel Alves Beuttemmuller for support in molecular biology. This study was supported by the National Council of Scientific and Technological Development (CNPq, grant number 305062/2015-8), the Brazilian Federal Agency for Support and Evaluation of Graduate Education (CAPES, process 88887.145705/2017-00), Foundation for Financing Studies and Projects (FINEP), and the Araucaria Foundation (FAP/PR).

\section{REFERENCES}

Alves M.P., Salgado R.L., Eller M.R., Vidigal P.M.P. \& Carvalho A.F. 2016. Characterization of a heat-resistant extracellular protease from Pseudomonas fluorescens $07 \mathrm{~A}$ shows that low temperature treatments are more effective in deactivating its proteolytic activity. J. Dairy Sci. 99(10):7842-7851. <http://dx.doi.org/10.3168/jds.2016-11236><PMid:27497896>

Bach H.J., Hartmann A., Schloter M. \& Munch J.C. 2001. PCR primers and functional probes for amplification and detection of bacterial genes for extracellular peptidases in single strains and in soil. J. Microbiol. Methods 44(2):173-182. <http://dx.doi.org/10.1016/S0167-7012(00)00239-6> $<$ PMid:11165346>

Baur C., Krewinkel M., Kranz B., Von Neubeck M., Wenning M., Scherer S., Stoeckel M., Hinrichs J., Stressler T. \& Fischer L. 2015. Quantification of the proteolytic and lipolytic activity of microorganisms isolated from raw milk. Int. Dairy J. 49:23-29. <http://dx.doi.org/10.1016/j.idairyj.2015.04.005>

Caldera L., Franzetti L., Van Coillie E., Vos P., Stragier P., Block J. \& Heyndrickx M. 2016. Identification, enzymatic spoilage characterization and proteolytic activity quantification of Pseudomonas spp. isolated from different foods. Food Microbiol. 54:142-153. <http://dx.doi.org/10.1016/j.fm.2015.10.004>

Capodifoglio E., Vidal A.M.C., Lima J.A.S., Bortoletto F., D’Abreu L.F., Gonçalves A.C.S., Vaz A.C.N., Baliero J.C.C. \& Saran Netto A.S. 2016. Lipolytic and proteolytic activity of Pseudomonas spp. isolated during milking and storage of refrigerated raw milk. J. Dairy Sci. 99(7):5214-5223. <http:// dx.doi.org/10.3168/jds.2015-10453> <PMid:27085402>
De Jonghe V., Coorevits A., Van Hoorde K., Messens W., Van Landschoot A., De Vos P. \& Heyndrickx M. 2011. Influence of storage conditions on the growth of Pseudomonas species in refrigerated raw milk. Appl. Environ. Microbiol. 77(2):460-470. <http://dx.doi.org/10.1128/AEM.00521-10> <PMid:21115713>

Dogan B. \& Boor J.K. 2003. Genetic diversity and spoilage potentials among Pseudomonas spp. isolated from fluid milk products and dairy processing plants. Appl. Environ. Microbiol. 69(1):130-138.<http://dx.doi.org/10.1128/ AEM.69.1.130-138.2003><PMid:12513987>

Ertan H., Cassel C., Verma A., Poljak A., Charlton T., Aldrich-Wright J., Omar S.M., Siddiqui A.S. \& Cavicchioli R. 2015. A new broad specificity alkaline metalloprotease from a Pseudomonas sp. Isolated from refrigerated milk: role of calcium in improving enzyme productivity. J. Mol. Catalysis B, Enzymatic 113:1-8. <http://dx.doi.org/10.1016/j.molcatb.2014.12.010>

Fairbairn D.J. \& Law B.A. 1986. Proteinases of psychrotrophic bacteria: their production, properties, effects and control. J. Dairy Res. 53(1):139-177. <http://dx.doi.org/10.1017/S0022029900024742> <PMid:3007589>

Hakiminia F., Ranjbar B., Khalifeh K. \& Khajeh K. 2013. Kinetic and thermodynamic properties of Pseudomonas fluorescence lipase upon addition of proline. Int. J. Biologic. Macromol. 55:123-126. <http://dx.doi.org/10.1016/j. ijbiomac.2012.12.046><PMid:23313821>

Hantsis-Zacharov E. \& Halpern M. 2007. Culturable psychrotrophic bacterial communities in raw milk and their proteolytic and lipolytic traits. Appl. Environ. Microbiol. 73(22):7162-7168. <http://dx.doi.org/10.1128/ AEM.00866-07><PMid:17890340>

Hu Z., Meng X.C. \& Liu F. 2016. Isolation and characterisation of lytic bacteriophages against Pseudomonas spp., a novel biological intervention for preventing spoilage of raw milk. Int. Dairy J. 55:72-78. <http://dx.doi. org/10.1016/j.idairyj.2015.11.011>

Huang X. \& Madan A. 1999. CAP3: A DNA sequence assembly program. Genome Research 9(9):868-877.<http://dx.doi.org/10.1101/gr.9.9.868> <PMid:10508846>

ISO 2009. ISO/TS 11059:2009 (IDF/RM 225: 2009) Milk and milk products: method for the enumeration of Pseudomonas spp. International Organization for Standardization, Geneva, Switzerland.

Kuddus M. \& Ramteke P.W. 2012. Recent developments in production and biotechnological applications of cold-active microbial proteases. Critic. Rev. Microbiol. 38(4):330-338. <http://dx.doi.org/10.3109/1040841X.2012.678477> <PMid:22849713>

Kumar S., Stecher G. \& Tamura K. 2016. MEGA7: Molecular Evolutionary Genetics Analysis version 7.0 for bigger datasets. Mol. Biol. Evol. 33(7):18701874. <http://dx.doi.org/10.1093/molbev/msw054><PMid:27004904>

Law B.A. 1991. Enzymes of psychrotrophic bacteria and their effects on milk and milk products. J. Dairy Res. 46(03):573-588. <http://dx.doi. org/10.1017/S0022029900017611>

Lin H., Shavezipur M., Yousef A. \& Maleky F. 2016. Prediction of growth of Pseudomonas fluorescens in milk during storage under fluctuating temperature. J. Dairy Sci. 99(3):1822-1830. <http://dx.doi.org/10.3168/ jds.2015-10179><PMid:26723126>

Matéos A., Guyard-Nicodème M., Baglinière F., Jardin J., Gaucheron F., Dary A., Humbert G. \& Gaillard J.L. 2015. Proteolysis of milk proteins by AprX, an extracellular protease identified in Pseudomonas LBSA1 isolated from bulk raw milk, and implications for the stability of UHT milk. Int. Dairy J. 49:78-88. <http://dx.doi.org/10.1016/j.idairyj.2015.04.008>

Nan L., Ren G., Wang D. \& Yang K. 2016. Antibacterial performance of Cubearing stainless steel against Staphylococcus aureus and Pseudomonas aeruginosa in whole milk. J. Mater. Sci. Tech. 32(5):445-451. <http:// dx.doi.org/10.1016/j.jmst.2016.01.002>

Oh Y.S., Shih L., Tzeng Y.M. \& Wang S.L. 2000. Protease produced by Pseudomonas aeruginosa $\mathrm{K}-187$ and its application in the deproteinization of shrimp and crab shell wastes. Enzyme Microb. Technol. 27(1/2):3-10. <http://dx.doi. org/10.1016/S0141-0229(99)00172-6><PMid:10862895> 
Oliveira G.B.D., Favarin L., Luchese R.H. \& McIntosh D. 2015. Psychrotrophic bacteria in milk: How much do we really know? Braz. J. Microbiol. 46(2):313-321. <http://dx.doi.org/10.1590/S1517-838246220130963> <PMid:26273245>

Osborne C.A., Galic M., Sangwan P. \& Janssen P.H. 2005. PCR-generated artefact from 16S rRNA gene-specific primers. FEMS Microb. Lett. 248(2):183-187. <http://dx.doi.org/10.1016/j.femsle.2005.05.043> <PMid:15961258>

Palomba R., Formisano G., Arrichiello A., Auriemma G. \& Sarubbi F. 2017. Development of a laboratory technique for the evaluation of protease enzymes activity in goat and sheep milk. Food Chem. 221:1637-1641. <http://dx.doi.org/10.1016/j.foodchem.2016.10.125><PMid:27979140>

Ribeiro Júnior J.C., Tamanini R., Silva L.C.C. \& Beloti V. 2015. Quality of milk produced by small and large dairy producers. Semina, Ciênc. Agrárias 36:883-888

Ribeiro Júnior J.C., Tamanini R., Soares B.F., Oliveira A.M., Silva F.G., Silva F.F., Augusto N.A. \& Beloti V. 2016. Efficiency of boiling and four other methods for genomic DNA extraction of deteriorating spore-forming bacteria from milk. Semina, Ciênc. Agrárias 37:3069-3078.

Scatamburlo T.M., Yamazi A.K., Cavicchioli V.Q., Pieri F.A. \& Nero L.A. 2015. Spoilage potential of Pseudomonas species isolated from goat milk. J. Dairy Sci. 98(2):759-764. <http://dx.doi.org/10.3168/jds.2014-8747> $<$ PMid:25497792>

Sørhaug T. \& Stepaniak L. 1997. Psychrotrophs and their enzymes in milk and dairy products: quality aspects. Trends Food Sci. Technol. 8(2):35-41. <http://dx.doi.org/10.1016/S0924-2244(97)01006-6>

Spilker T., Coenye T., Vandamme P. \& LiPuma J.J. 2004. PCR-based assay for differentiation of Pseudomonas aeruginosa from other Pseudomonas species recovered from cystic fibrosis patients. J. Clin. Microbiol. 42(5):2074-2079. <http://dx.doi.org/10.1128/JCM.42.5.2074-2079.2004><PMid:15131172>

Stoeckel M., Lidolt M., Stressler T., Fischer L., Wenning M. \& Hinrichs J. 2016. Heat stability of indigenous milk plasmin and proteases from Pseudomonas: A challenge in the production of ultra-high temperature milk products. Int. Dairy J. 61:250-261. <http://dx.doi.org/10.1016/j.idairyj.2016.06.009>

Stuknytė M., Decimo M., Colzani M., Silvetti T., Brasca T., Cattaneo S., Aldini G. \& De Noni I. 2016. Extracellular thermostable proteolytic activity of the milk spoilage bacterium Pseudomonas fluorescens PS19 on bovine caseins. J. Dairy Sci. 99(6):4188-4195. <http://dx.doi.org/10.3168/jds.201610894><PMid:26995139>

Teh K.H., Lindsay D., Palmer J., Andrewes P., Bremer P. \& Flint S. 2014 Proteolysis in ultra-heat-treated skim milk after exposure to multispecies biofilms under conditions modelling a milk tanker. Int. J. Dairy Technol. 67(2):176-181. <http://dx.doi.org/10.1111/1471-0307.12114>

Vidal A.M.C., Saran Netto A., Vaz A.C.N., Capodifóglio E., Gonçalves A.C.S., Rossi G.A.M., Figueiredo A.S. \& Ruiz V.L.A. 2017. Pseudomonas spp.: contamination sources in bulk tanks of dairy farms. Pesq. Vet. Bras. 37(9):941-948. <http:// dx.doi.org/10.1590/s0100-736x2017000900008>

Wright E.A., Di Lorenzo V., Trappetti C., Liciardi M., Orru G., Viti C., Bronowski C., Hall A.J., Darby A.C., Oggioni M.R. \& Winstanley C. 2015. Divergence of a strain of Pseudomonas aeruginosa during an outbreak of ovine mastitis. Vet. Microbiol. 175(1):105-113. <http://dx.doi.org/10.1016/j. vetmic.2014.11.011><PMid:25475851>

Xin L., Meng Z., Zhang L., Cui Y., Han X. \& Yi H. 2017. The diversity and proteolytic properties of psychrotrophic bacteria in raw cows' milk from North China. Int. Dairy J. 66:34-41. <http://dx.doi.org/10.1016/j.idairyj.2016.10.014> 